\title{
CTGF Gene
}

National Cancer Institute

\section{Source}

National Cancer Institute. CT GF Gene. NCI Thesaurus. Code C62457.

This gene is involved in mitogenesis. 